\title{
NEW GYMNOSPERM WOOD FOSSILS, A SEED-OVULE STRUCTURE, AND A NEW GENERIC AFFINITY TO CEDROXYLON CANOASENSE RAU FROM THE PERMIAN AND TRIASSIC-JURASSIC OF SOUTHERN BRAZIL
}

\author{
ALEXANDRA CRISAFULLI \\ Facultad de Ciencias Exactas y Naturales y Agrimensura, Universidad Nacional del Nordeste y CECOAL-CONICET \\ Ruta 5, km 2,5 - 3400, Corrientes, Argentina. alexandracrisafulli@hotmail.com \\ $†$ RAFAEL HERBST \\ Instituto Superior de Correlación Geológica-CONICET, Las Piedras 201 7º - 4000 San Miguel de Tucumán, Argentina.
}

TANIA LINDNER DUTRA

Programa de Pós-Graduação em Geologia, Universidade do Vale do Rio dos Sinos - UNISINOS, Av. Unisinos 950, 93022-000, Brazil.dutratl@gmail.com

\begin{abstract}
Two new species of gymnosperm wood from the Triassic-Jurassic of Brazil are here described [Lobatoxylon kaokense Kräusel and Chapmanoxylon jamuriense (Maheswari) Pant \& Singh], and a new age and generic affinity are proposed for Cedroxylon canoasense Rau. To the latter, originally considered as Triassic, an early Permian age is proposed based on its lithological relationships and the location of its discovery. Additionally, a seed-ovule structure linked to Kaokoxylon zalesskyi (Sahni) Maheswari wood materials, is illustrated and analyzed. All materials were identified in the sedimentary rocks exposed in the central E-W belt (Central Depression) of the State of Rio Grande do Sul, South Brazil, where is exposed the Gondwana Sequence of Paraná Basin. The new wood taxa here described increase the number of known genera in the Triassic-Jurassic of southern Brazil. Nevertheless, the arboreal vegetation of gymnosperms remains impoverished when compared with that present in the Permian deposits. Survivors from the Permian-Triassic extinction, they show that new and more evolved types were capable to explore and adapt to the new landscapes resulting from the environmental changes that affected the interior continental areas of Western Gondwana.
\end{abstract}

Keywords: fossil woods, seed-ovule, Gymnosperms, Ginkgophyta, Permian, Triassic-Jurassic.

RESUMO - Duas novas espécies de lenhos gimnospérmicos do Triássico-Jurássico do sul do Brasil são aqui descritas [Lobatoxylon kaokense Kräusel e Chapmanoxylon jamuriense (Maheswari) Pant \& Singh], e uma nova afinidade genérica é proposta para Cedroxylon canoasense Rau. Esta última forma, originalmente considerada como Triássica, por suas relações litológicas e local do achado é aqui proposta como referente ao Eopermiano. Além disto, uma semente identificada junto a fragmentos de lenho de Kaokoxylon zalesskyi (Sahni) Maheswari, é ilustrada e analisada. No conjunto o material lenhoso foi identificado na faixa central de sentido E-W do Rio Grande do Sul (Depressão Central), onde afloram as litologias da Sequência Gondwana da Bacia do Paraná. As duas novas formas aqui descritas ampliam o número de táxons lenhosos conhecidos para o Triássico-Jurássico no sul do Brasil, apesar de atestar uma vegetação arbórea de gimnospermas mais empobrecida, quando comparada com aquela conhecida para o Permiano. Sobreviventes da Extinção Permo-Triássica demonstram, por outro lado, que novos tipos mais evoluídos foram capazes de explorar e se adaptar às novas paisagens resultantes das mudanças ambientais e climáticas que afetaram as áreas do interior do Gondwana Ocidental.

Palavras-chave: lenhos, óvulo-semente, Gimnospermas, Ginkgophyta, Permiano, Triássico-Jurássico.

\section{INTRODUCTION}

A huge amount of gymnosperm petrified fossil woods (Beltrão, 1965; Santos \& Moreira, 1987; Guerra-Sommer \& Scherer, 2002) were known since the XIX century in the State of Rio Grande do Sul (Ave-Lallemant, 1880; Isabelle, 1883), mainly concentrate in the Central Depression area (Figure 1). The fossil woods remains were in general found in the fluvial channel deposits included in the Santa Maria (Middle-Upper Triassic) and Caturrita (Upper Triassic-Lower Jurassic) formations, which corresponds to the Gondwana I and II sequences of Paraná Basin from Milani et al. (1998, 2007). Their occurrence become more impressive in the youngest levels of Caturrita Formation (CF), leading Faccini et al. (2003) to propose an informal stratigraphic unit, the "Mata Sandstones", separated from CF by a time gap (Figure 2). 
In it, a real petrified forest, was detected in westernmost outcrops, in the surroundings of the cities of Mata and São Pedro do Sul (Figure 1).

Zerfass et al. $(2003,2004)$ included all those Mesozoic strata in the Santa Maria Supersequence, a second order succession, with three second orders sequences (Santa Maria 1,2 , and 3). From that, the last two correspond to the "MiddleUpper Triassic sequences" from Faccini \& Paim (2001). The permineralized woods appears in the top of Santa Maria 2 sequence (SM2), and are still more abundant and diverse at SM3 (= 'Mata sandstones'), from where came part of the herein described wood pieces. Initially considered restricted to the Upper Triassic, recent contributions that analyze the conchostracan faunas and dinosaurs ichnites, allow to confirm that Lower Jurassic rocks occurs at least in SM3 (Barboni \&
Dutra, 2013; Soares et al., 2014; Rohn et al., 2014; Jenisch et al., 2017).

However, conifer fossil woods are a minor component of the basal SM2, where leaf assemblages of pteridosperms and Ginkgophyta dominate (Guerra-Sommer \& CazzulloKlepzig, 2000; Barboni \& Dutra, 2015), accompanied by a characteristic tetrapod fauna of Carnian age (Zerfass et al., 2003).

\section{Previously known fossil wood materials}

The petrified woods of upper SM2 and of SM3 are represented by fragmentary to entire trunks, which varies between 70-100 $\mathrm{cm}$ in diameter, and can reach more than 12 $\mathrm{m}$ long (Figures $3 \mathrm{~A}-\mathrm{C}$ ), most of them reworked and found dispersed in Quaternary soils. A list of the described material is furnished in Table 1.
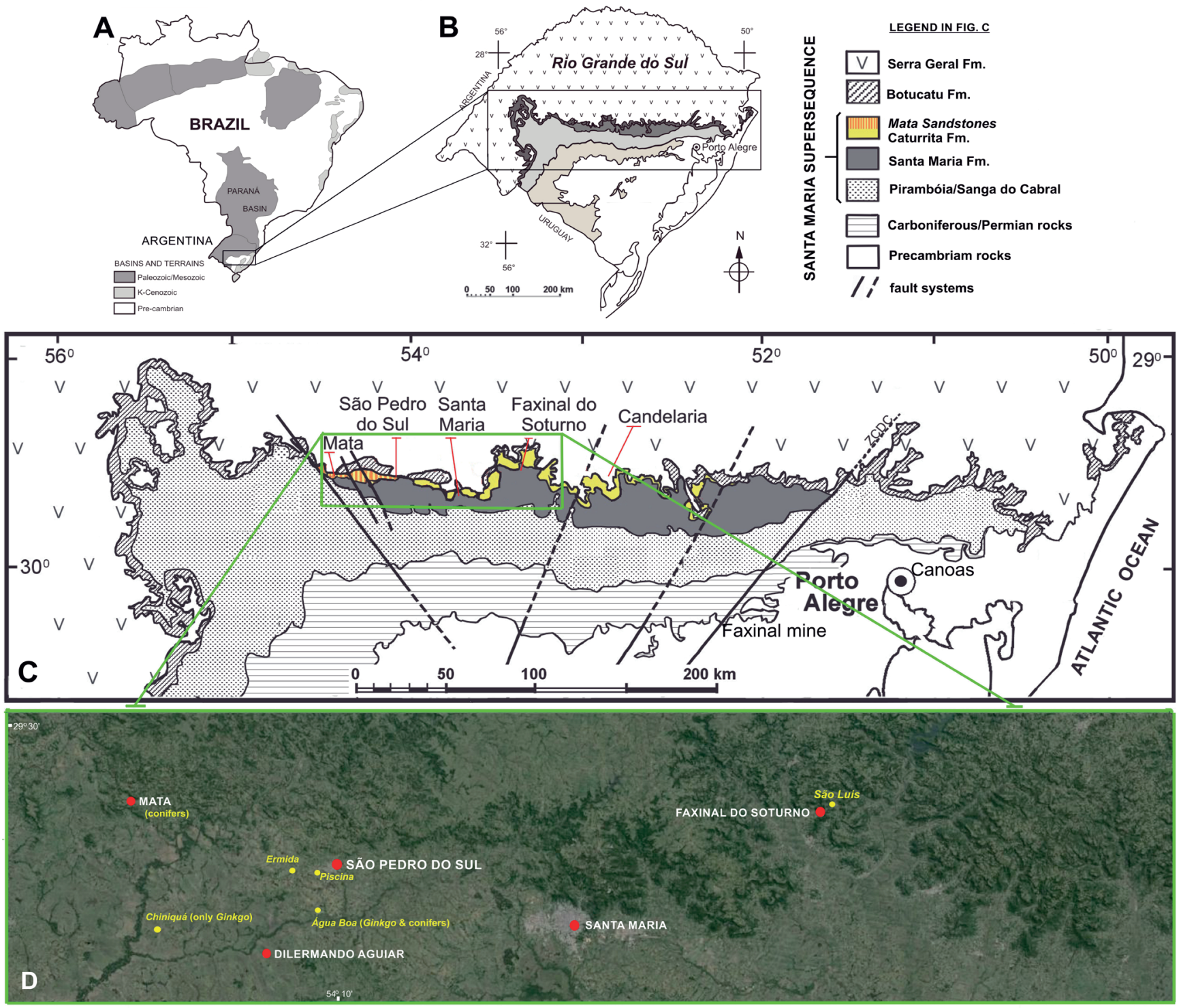

Figure 1. A, Location of the main Paleozoic and Mesozoic intracratonic basins in Brazil; B, State of Rio Grande do Sul and the broad E-W belt (Central Depression) that exposes the Permian and Triassic deposits of Paraná Basin are exposed; $\mathbf{C}$, detail of B, highlightening the distribution of the sedimentary units of the Santa Maria Supersequence from Zerfass et al. (2003), its correlate lithostratigraphic units and the main local places with Triassic and Jurassic fossils; D, detail of the localities (red) and outcrops (yellow) were permineralized fossil woods were found (original picture from Gloogle Earth). See Table 1 to the proposed ages and taxa. A-C, modified from Faccini et al. (2003). 


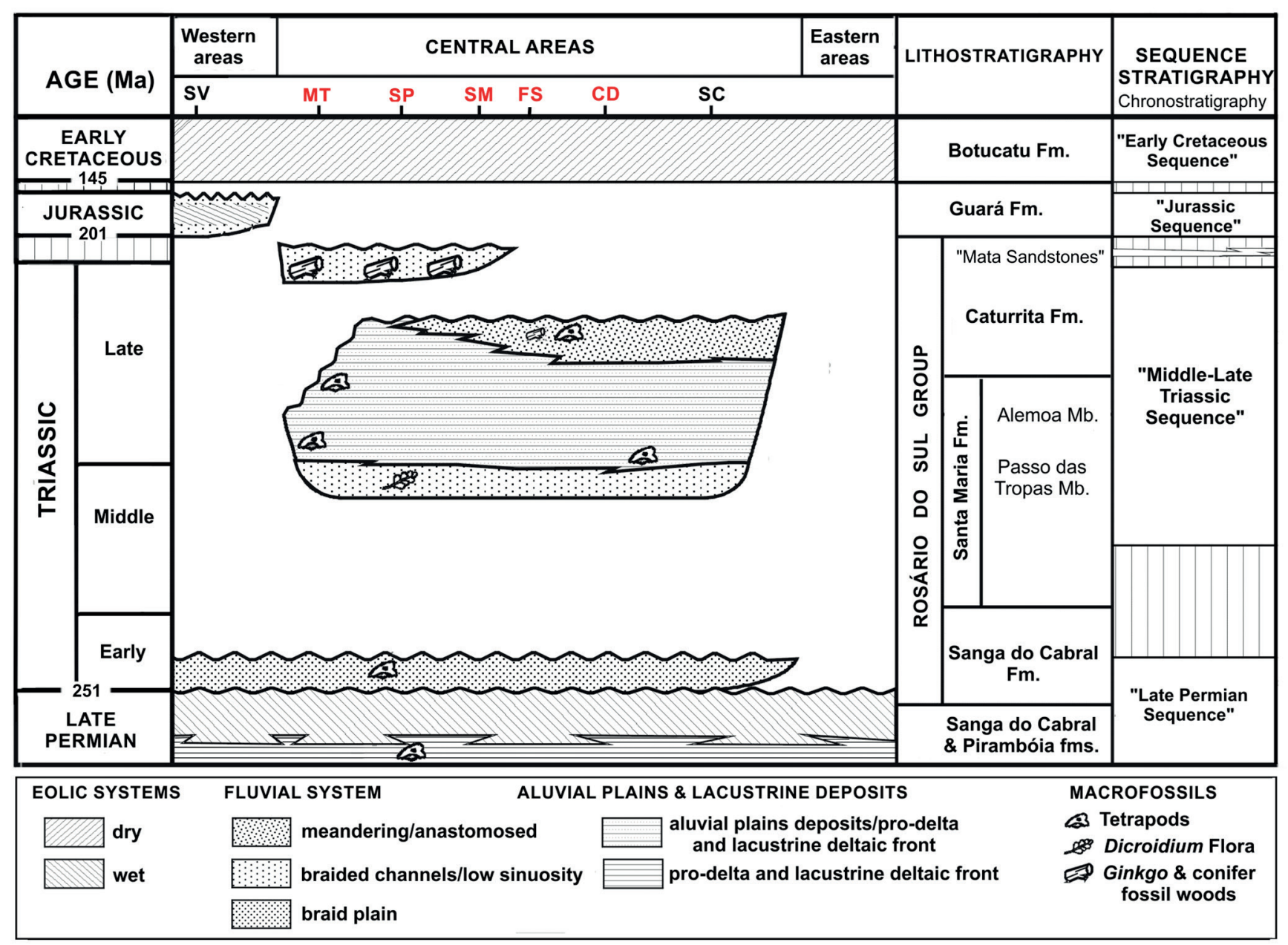

Figure 2. Chronological, lithological and sequential stratigraphic chart proposed by Faccini \& Paim (2001) for the Mesozoic of Rio Grande do Sul. The location of the lithostratigraphic units, depositional structures and ages are actualized in accord with the newly described fossil assemblages (see text). The red letters indicate the localities with fossil wood occurrences. Ages from Cohen et al. (2013, updated). Abbreviations: SV, São Vicente do Sul; MT, Mata; SP, São Pedro do Sul; SM, Santa Maria, FS, Faxinal do Soturno; CD, Candelária; SC, Santa Cruz do Sul.

Table 1. Previously described wood taxa of Caturrita and Santa Maria formations in Rio Grande do Sul. In bold, the new ages proposed for the sedimentary succession contain the fossil woods by the data herein commented. Abbreviations: Tr, Late Triassic; J, Early Jurassic; SPS, São Pedro do Sul; FS, Faxinal do Soturno. Symbol: ?, reflect an uncertain age or source of the sample.

\begin{tabular}{lccl}
\hline \multicolumn{1}{c}{ Taxa } & Age & Outcrop/Locality & \multicolumn{1}{c}{ References } \\
\hline Rhexoxylon brasiliensis (Corystosp.) & $\mathrm{Tr}$ & near SPS (not precise) & Herbst \& Lutz, 1988 \\
"Araucarioxylon" spp. (conifer) & $\mathrm{Tr} / \mathrm{J} ?$ & Cerro da Ermida, SPS & Minello (1994b) \\
Baieroxylon cicatricum (Ginkgoaceae) & $\mathrm{Tr}$ & Chiniquá/Agua Boa, SPS & Minello (1994b)/Bardola et al. (2009) \\
Sommerxylon spiralosus (Taxaceae) & $\mathrm{J}$ & São Luis outcrop, FS & Pires \& Guerra-Sommer (2004) \\
Kaokoxylon zalesskyi (conifer) & $\mathrm{J}$ & São Luis outcrop, FS & Crisafulli \& Dutra (2009) \\
Agathoxylon africanum (conifer) & $\mathrm{J} ?$ & Soturno River, FS & Crisafulli et al. (2016) \\
Chapmanoxylon jamuriense (conifer) & $\mathrm{J} ?$ & unknow, SPS & this work \\
Chapmanoxylon sp. cf. C. jamuriense & $\mathrm{J} ?$ & Soturno river, FS & Crisafulli et al. (2016) \\
Megaporoxylon kaokense (conifer) & $\mathrm{J} ?$ & Soturno river, FS & Crisafulli et al. (2016) \\
Lobatoxylon kaokense (conifer) & $\mathrm{J} ?$ & unknow, SPS & this work
\end{tabular}


Few specimens were found in situ (sensu Martínez \& Santonja, 1994) and until now, they are exclusive from the areas of Mata and São Pedro do Sul. The reworked materials were for a long time found during agricultural activities, and most of them were sliced, polished and sold to scientific institutions and collectors. In Mata, however, they were catalogued and placed on floors and walls of different buildings, public parks, and squares (Figures $3 \mathrm{~A}-\mathrm{C}$ ), a strategy of Priest Daniel Cargnin, an amateur paleontologist, to guarantee its preservation near the source area. Today these material are maintained in the field areas where occur (like in the Paleobotanical Garden of Mata) or housed in the regional museums. Those of São Pedro do Sul are also exposed in the Main Square (Figure 3D) and, when detected in the original levels (Figure 3E), allow to confirm its relation with the fluvial sandbars of CF. They are aligned in relation to the sandstone dunes (Figures 3E-F) in a preferential NNE direction, the same of the main river flow of CF.

On other side, in the more southern Água Boa and Chiniquá expositions (Figure 1), they are exclusive by the conjunct occurrence of conifers (mainly related with the Araucariaceae) and Ginkgophyta (Bardola et al., 2010), and thus support the older ages proposed by the stratigraphic models. In spite of the wealth of specimens in the whole region and the studies made (Pires \& Guerra-Sommer, 2004; Bardola et al., 2009, 2010; Crisafulli et al., 2009, 2016), their description is still far from providing a complete understanding of its diversity.

The pioneer work with fossil woods of the Paraná Basin was made by Rau (1933), a German specialist in coal mines prospection. Based on the anatomical features preserved in some charcoalified fragments, he nominated the new species Cedroxylon canoasense. In its notes, he indicates that it was found in a well $6 \mathrm{~m}$ deep, made in white clay deposits (the "tabatinga bermeja" for Rau), near the city of Canoas (Figure 1), and associated by him with the Triassic Santa Maria Formation (=basal SM2). However, the absence of Triassic levels in the region allow to infer that Rau's material actually come from Permian units, and specifically, from the Rio Bonito Formation, distinguished by its white mudstones (with kaolinite), and charcoal lenses (Jasper et al., 2011) in the Paraná basin sedimentary column. Additionally, DeganiSchmidt \& Guerra-Sommer (2016), indicate the presence of Agathoxylon-type of wood at the Faxinal coal-mine. The specimen of Rau (1933) seems to be lost, but based in the original diagnosis and its poor illustrations, is herein proposed that represents a form of Agathoxylon (Dadoxylon) Hartig. Taking this into account, the first work with a taxonomic focus with the Triassic xyloflora of Rio Grande do Sul was that of Herbst \& Lutz (1988). Based on samples from the Walter Ilha Museum in São Pedro do Sul, they described and proposed a new genus and species, Rhexoxylon brasiliensis, linked to the Corystospermales. Later, Minello (1994a), working in the Ermida outcrop, and based in the anatomy of a secondary xylem, proposed a relationship of this permineralized woods with Araucarioxylon (=Agathoxylon), what was afterwards confirmed by Guerra-Sommer et al. (1999).
Pires \& Guerra-Sommer (2004), working with parautochtonous materials of the surroundings of Faxinal do Soturno county (São Luis outcrop, Figure 1), described the new genus and species Sommerxylon spiralosus, considered related to the Taxaceae. In the same levels, Crisafulli \& Dutra (2009) studied an autochtonous conifer wood (with roots in situ), and considered it, by the anatomical features, comparable to Kaokoxylon zalesskyi (Sahni) Maheswari. Both materials come from the basal levels of a lake deposit, deposited over massive crevasse splay fine sands deposits, and together represents the younger levels of CF in the area.

Bardola et al. (2009) described a Ginkgophyta wood (Baieroxylon cicatricum Prasad \& Lele) found at Chiniquá outcrop and associated to a tetrapod fauna characteristic of the Santa Maria Formation (Table 1). Other works also focused the taphonomic process involved in the fossil wood permineralization by silica minerals (Bolzon \& GuerraSommer, 1994; Minello, 1993, 1994a, b) and in the applying of growth rings to confirm the seasonal conditions of the paleoclimate (Bolzon, 1993; Alves et al., 2005; Pires et al., 2005).

\section{MATERIAL AND METHODS}

The two new conifer woods herein described are based on specimens identified in the fossil collection of the Paleontological Museum Walter Ilha, at São Pedro do Sul, and result from collections made in the 1960 decade. They are kept at the Museum under the acronym CPWI (field number CPV E1). One ovule and seed, tridimensionally preserved, found linked to a lignified portion (cone axis?) in the same beds that contain the $K$. zalesskyi wood remains (Crisafulli \& Dutra, 2009) is also herein described.

Thin sections (transversal, longitudinal radial and tangential) have been prepared in the usual way. The anatomical nomenclature is based on García Esteban et al. (2002), and the terminology in the descriptions, is that from the list of microscopic features used by IAWA (2004). To the taxonomic treatment and description of araucaria related reproductive structures, the nomenclature proposed by Stockey (1978) and Stockey \& Taylor (1978) was used. A minimum of 25 measurements was made, quoting the media, and minimum and maximum values in parentheses. The specimen described as "conifer seed" from the São Luis locality is kept at the Paleobotanical Collection of the Universidade do Vale do Rio dos Sinos (UNISINOS), in the city of São Leopoldo, Rio Grande do Sul, under the acronym ULVG-8352.

The original specimen of Cedroxylon canoasense Rau seems to be lost, but Philippe \& Thevenard (1996) quote some slides found at the Humboldt Museum of Natural Sciences in Berlin (MNB collection numbers: 25/6r-359) which apparently belong to it (see below for more data). Although badly preserved, we assume here that they correspond to Rau's species. 

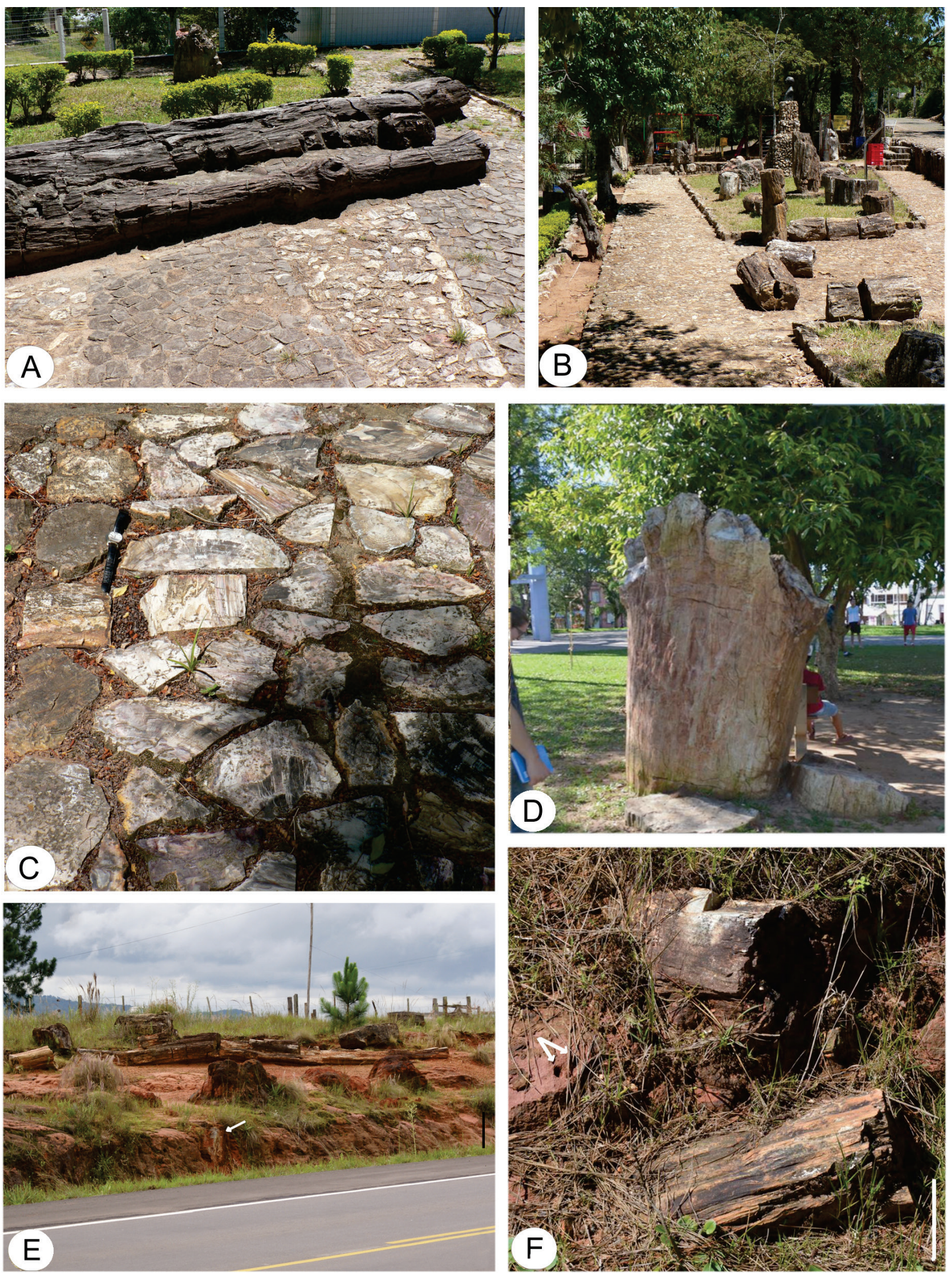

Figure 3. The distinct Lower Mesozoic big woods of the Caturrita Formation ("Mata Sandstones") in the western area of central Rio Grande do Sul. A-B, large stems lying near the church and in the main square at the city of Mata; $\mathbf{C}$, detail of a path paved with polished fossil wood pieces in Mata; $\mathbf{D}$, fossil wood stems exposed in the main square of the São Pedro do Sul Municipality; E, organized disposition of big stems over the margins of BR 290 highway at Piscina outcrop (Paleobotanical Monument), São Pedro do Sul, and an in situ fossil woods (arrow) in the sand bar deposits (scale bar $50 \mathrm{~cm}$ ). F, detail of the wood remains horizontal and multidirectionally orientated, in the mid-channel bar deposits of Piscina outcrop, characterized by intense bioturbation (arrows). Scale bar in figures E-F $=1 \mathrm{~m}$. 


\section{SYSTEMATIC PALEONTOLOGY}

\author{
Division TRACHEOPHYTA Sinnott, 1935 ex Cavalier- \\ Smith, 1998
}

Class SPERMATOPSIDA Serbet \& Rothwell, 1995

Order CONIFERALES Engler, 1897

Family incertae sedis

Lobatoxylon Kräusel, 1956

Type species: Lobatoxylon pedroi (Zeiller) Kräusel, 1956.

Lobatoxylon kaokense Kräusel, 1956

(Figures 4-5)

1956 Lobatoxylon kaokense Kräusel, 37: 447-453, tab. 2, fig. 10; tab. 4, fig., 17; tab., 5 figs. 18-21.

2001 Lobatoxylon kaokense Kräusel, in: Lutz et al., p. 123-125, fig. 5, tab. 1.

Material. CPWI 713 (field number CPV E1 067); slides CPWI 713a,b,c., São Pedro do Sul, Rio Grande do Sul, Brazil. Description. Rounded slice of silicified wood about $13 \times 9 \mathrm{~cm}$ in diameter, preserving a 4- lobulated heterogeneous, compact, nontabicated pith, primary xylem, and secondary xylem, but not the cortex (Figures 4, 5A-B). Parenchyma cells are rounded, their radial and tangential average diameters are $30 \mathrm{x}$ $33(23 \times 35 ; 30 \times 38) \mu \mathrm{m}$. Secretory circular cells, isolated or in groups, are present (Figures 5B-C). Scarce sclerenchymatous polygonal cells are also observed. Primary xylem with cuneiform projections, endarch protoxylem (Figure 5C). Growth rings present. Secondary xylem picnoxylic; tracheids are quadrangular in traverse section. An average of six (4-8) cells separate the radii (Figure 5D). In a longitudinal radial section, tracheids with uniseriate, circular, contiguous, biseriate and triseriate bordered pits (Figures 4, 5E-F). Cross fields with 4-6 araucarioid pits; in longitudinal tangential section radii are uni- and partially biseriate, averaging four to ten cells high (Figure 4).

Discussion. Some authors, like Berthelin et al. (2004) and Merlotti \& Kurzawe (2011) still use the generic epithet Trigonomyelon Walton for Lobatoxylon Kräusel, but as shown by Lutz et al. (2001), who made a synthesis about it based on the arguments provided by Kräusel (1956), the latter name should be used. The four-lobulated pith and the pitting type of the longitudinal radial tracheidal walls of the secondary xylem allows to assimilate this specimen to the South African L. kaokense Kräusel and separate it from the other species recorded to this genus in the Permian, of Brazil: L. pedroi (Zeiller), originally named as Dadoxylon pedroi by Zeiller (1895), which was made the type species of the genus; from India: L. raniganjense (Maheshwari,1967; Prasad, 1986) and that from the Upper Triassic of India and Chile: L. kamthiensis (Prasad) Lutz, Crisafulli \& Herbst (in Lutz et al., 2001). The distinctive characters are the absence of secretory canals in the pith, the hexagonal pits on the radial tracheidal walls and the presence of triseriate pits and sclerenchymatic cells in

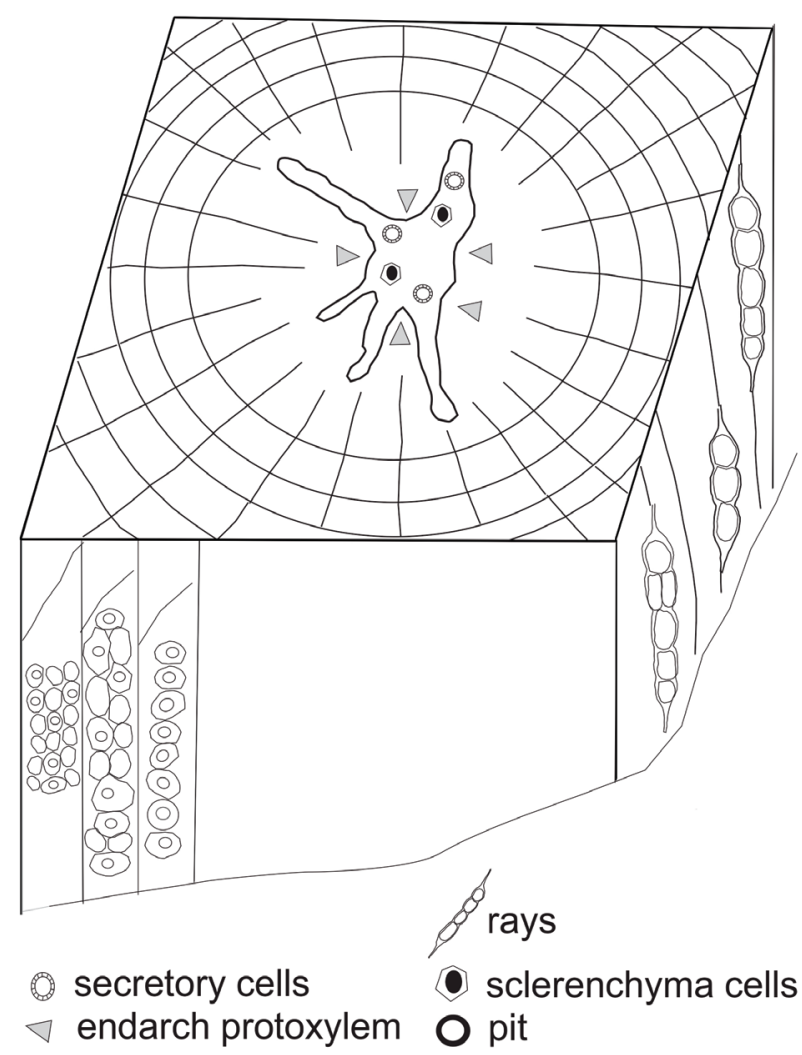

Figure 4. Lobatoxylon kaokense Kräusel. Block diagram showing wood characters in transversal, radial and tangential longitudinal section.

the pith, all absent in L. kamthiensis. The species L. pedroi is different because in L. kaokense the trilobite pith and its secretory canals is absent, and has a higher number of pits (4-6) in its fields, distinct from the 1-2 pits from L. pedroi.

Chapmanoxylon Pant \& Singh, 1987

Type species. Chapmanoxylon jamuriense (Maheshwari) Pant \& Singh, 1987.

Chapmanoxylon jamuriense (Maheshwari) Pant \& Singh, 1987

(Figure 6)

1966 Dadoxylon jamuriense Maheshwari, 13(2):148, lám. 1, fig. 1-5, lám. 2, fig 6.

1972 Damudoxylon jamuriense (Maheshwari) Maheshwari, 138: 11.

1987 Chapmanoxylon jamuriense (Maheshwari) Pant \& Singh, 203, p. 21, tab. 3.

2008 Chapmanoxylon jamuriense (Maheshwari) Pant \& Singh, in: Crisafulli \& Herbst, 5: 739-740, fig 3.1-4 and 4.1-2.

2009 Chapmanoxylon jamuriense (Maheshwari) Pant \& Singh, in Crisafulli et al., 5:7-8, figs. 5D-G, 6A-E.

2012 Chapmanoxylon jamuriense (Maheshwari) Pant \& Singh, in: Leiva Veron et al., 8:71, figs. 3C-D. 

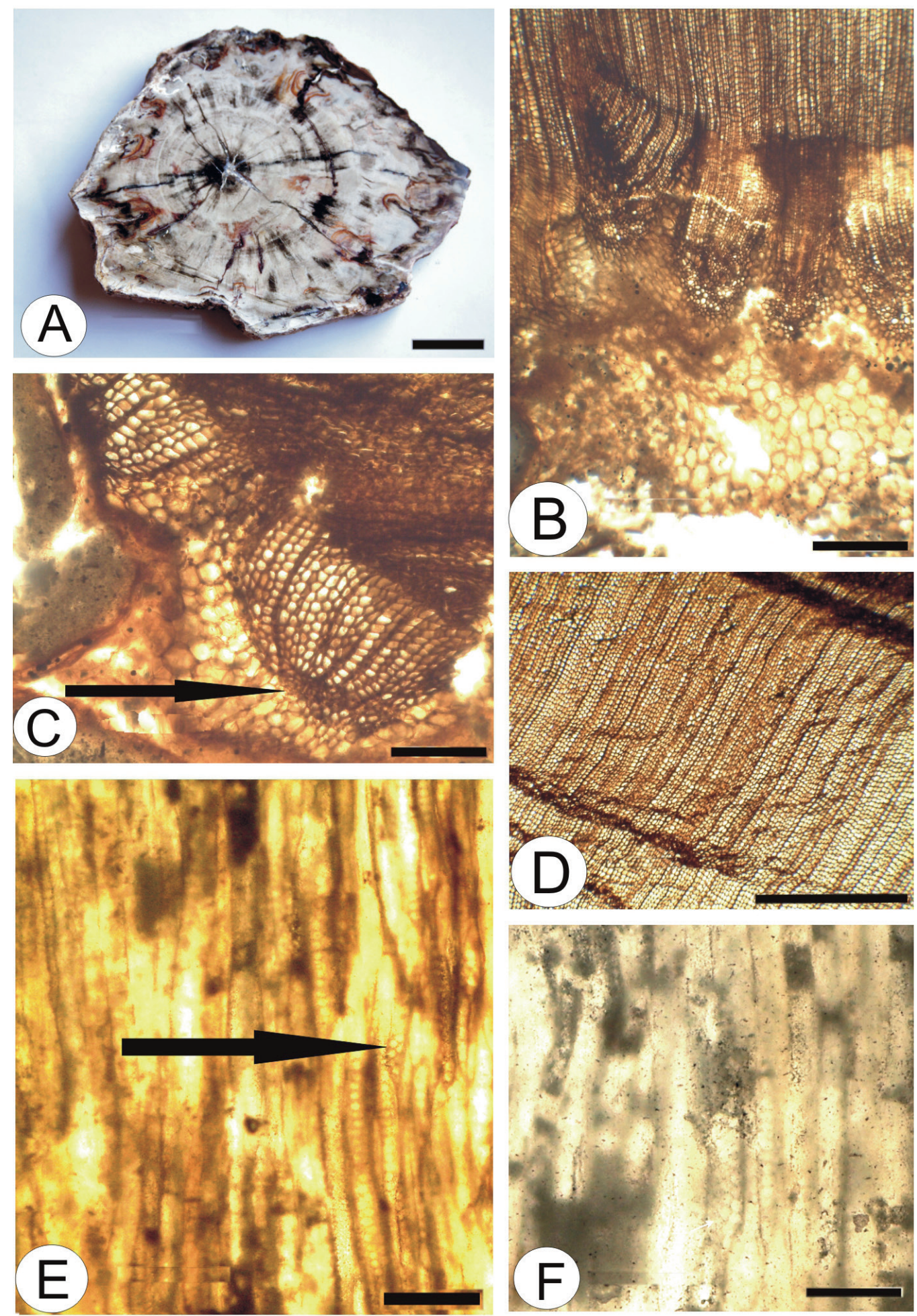

Figure 5. Lobatoxylon kaokense Kräusel. A-D, transverse sections (CPWI 713a): A, general aspect of the wood (CPWI 713); B, parenchimatic pith, primary xylem with wedge-shaped projections and pycnoxilic secondary xylem; $\mathbf{C}$, detail of B: arrow indicates the protoxylem; $\mathbf{D}$, secondary xylem with growth rings. $\mathbf{E}-\mathbf{F}$, Longitudinal radial section (CPWI 713 b), showing pits on the tracheidal walls: $\mathbf{E}$, uniseriate pits; arrow indicates biseriate, alternate pits. F, uniseriate and triseriate pits. Scale bars: $\mathrm{A}=5 \mathrm{~cm} ; \mathrm{B}=150 \mu \mathrm{m} ; \mathrm{C}, \mathrm{E}=100 \mu \mathrm{m} ; \mathrm{D}=400 \mu \mathrm{m} ; \mathrm{F}=70 \mu \mathrm{m}$. 

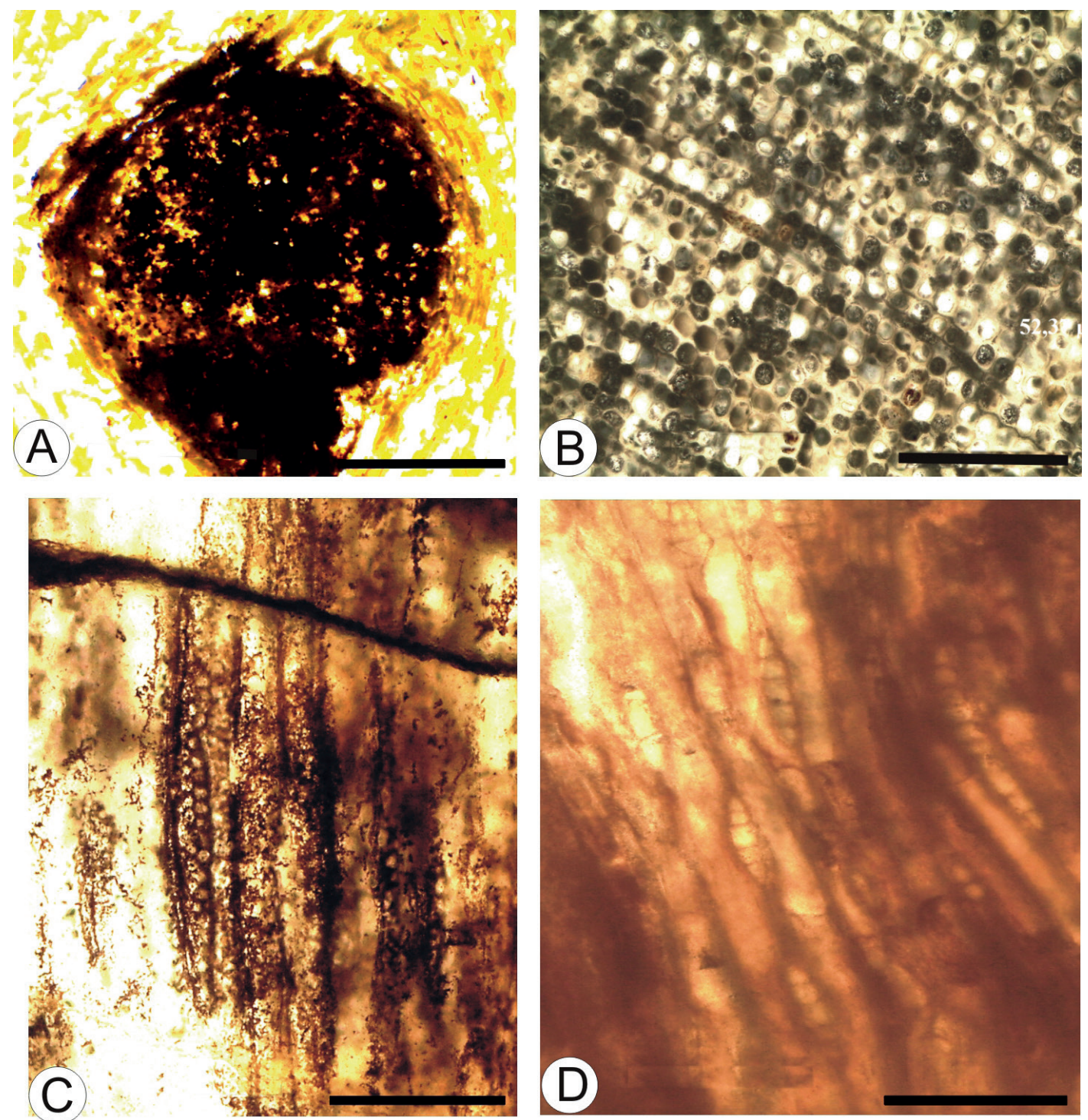

Figure 6. Chapmanoxylon jamuriense (Maheswari) Pant \& Singh (CPWI 714). A, longitudinal tangential section of secondary xylem, with detail of transversal section of the pith of the trace (CPWI 714c); B, transversal section showing tracheids of secondary xylem with dark contents (CPWI 714a); C, longitudinal radial section of secondary xylem, showing biseriate, sub- opposite pits on the tracheidal walls (CPWI 714b); D, uniseriate and lower rays (CPWI 714c). Scale bars: $\mathrm{A}=1 \mathrm{~mm} ; \mathrm{B}=330 \mu \mathrm{m} ; \mathrm{C}=160 \mu \mathrm{m} ; \mathrm{D}=240 \mu \mathrm{m}$.

Material. CPWI 714 (original field number CPE1 091); slides CPWI 714 a,b,c. Walter Ilha Museum, São Pedro do Sul, Rio Grande do Sul, Brazil.

Description. Rounded slice of silicified wood, circa $8 \mathrm{~cm}$ thick and about $20 \times 15 \mathrm{~cm}$ in diameter, preserving the pith, primary and secondary xylem, but without cortex. Pith circular, about $2.5 \mathrm{~cm}$ in diameter, homogeneous, compact, not tabicated and composed of rounded parenchyma cells in transverse section. Tangential and radial average diameters $55 \times 63(40 \times 50 ; 50 \times 60) \mu \mathrm{m}$. In the longitudinal radial section, they are rectangular. Primary xylem forming cuneiform projections; protoxylem endarch. Secondary xylem picnoxylic with marked growth rings and shearing zones (sensu Erasmus, 1976). In transversal section tracheids are rectangular; with radial and tangential average diameters of $42 \times 33(33 \times 25 ; 48 \times 33) \mu \mathrm{m} ; 6(4-7)$ tracheid separate radii
(Figure 6B). Radial walls of the secondary xylem cells with uni-to biseriate, circular, and contiguous to separate pits; the biseriate ones are alternate (Figure 6C). Cross fields with rounded pits. In longitudinal tangential section, the radial system is homogeneous. Radii are homocellular, uniseriate and low; average height is 5 (4-7) cells (Figure 6D).

Discussion. Chapmanoxylon is one of the few genera with a homogeneous pith and an araucarioid secondary xylem. The distribution of pits in the tracheids and cross fields, as well as the height of the non-articulate radii, justify the specific name of the present specimen. This species was also found in the Permian of Argentina (Solca Formation, Crisafulli \& Herbst, 2008), Uruguay (Tres Islas Formation, Crisafulli et al., 2009), Paraguay (Tacuary Formation, Leiva Verón et al., 2012) and in the Permian Raniganj Formation of India (Pant \& Singh, 1987). A specimen close to this species and referred as "cfr." was found in situ, in levels of Caturrita Formation outcropping 
at the Rio Soturno terraces, near Faxinal do Soturno County (Crisafulli et al., 2016, Table 1).

\section{Family ARAUCARIACEAE}

Agathoxylon Hartig, 1948

Type species. Agathoxylon cordaianum Hartig, 1848.
Agathoxylon canoasense (Rau) Crisafulli nov. comb.

(Figure 7)

1933 Cedroxylon canoasense Rau, 68, figs. 1-3.

1949 Xenoxylon canoasense (Rau), Kräusel, in: Kräusel, 89: (part 3): 188.

1996 Xenoxylon canoasense (Rau) Kräusel, in: Philippe \& Thevenard, 91: 357.
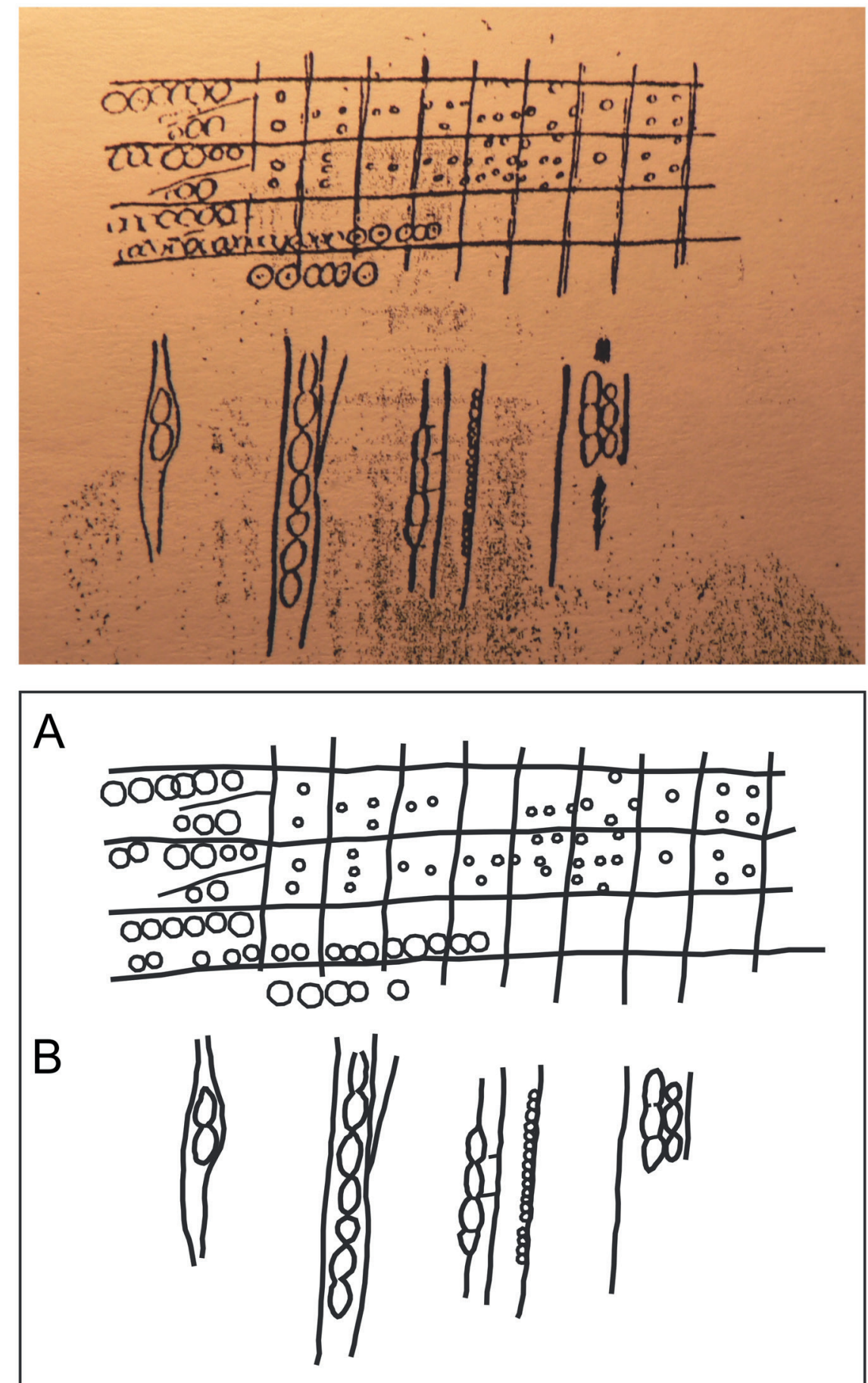

Figure 7. Agathoxylon canoasense (Rau) nov. comb., with the sketch from the original work of W. Rau (upper) and the more clear replica of it made by R. Herbst (low). A, longitudinal radial section of secondary xylem showing circular and contiguous uniseriate and biseriate, opposite, spaced pits, on the tracheidal walls and the arrangement of pits on the cross field. B, longitudinal tangential section showing uniseriate rays. 
Diagnosis. Taken textually that from Rau (1933, p. 68): "Bordered pits uniseriate, rarely opposite. If biseriate, generally one row is on a different level or separated by fine tracheid-wall. Bordered pits flattened above and below and appear elliptic. There are slightly and greatly flattened pits. But circular ones are also seen in the rows and peculiarly if isolated. There are no hexagonal or polygonal pits. Diameter of the bordered pits 9-15 $\mu \mathrm{m}$. Lenght of the markraysells $(*)$ 21-28 $\mu \mathrm{m}$. Breath of the markraysells 14-21 $\mu \mathrm{m}$. In tangential slices the markrays are uniseriate, only rarely biseriate. Resin canals or cells do not exist. Growth rings perspicuous on the transversal slice. Pits of the markrays are small (abietinoid ?Prof. Zimmermann)". (*): markraysells and markrays are original spellings.

Comments. Kräusel (1949, part 3, p. 188) proposed a new combination of this species with the genus Xenoxylon based only on the poor quality of the photographs and Rau's sketches (herein redrawn in its proper vertical orientation), but left it as "doubtful forms". From the description and the few illustrations given by the author and our interpretation, it seems clear that this species can be included more accurately in Agathoxylon Hartig in its present modern definition (Rößler et al., 2014). The genus Cedroxylon initially proposed by Rau (1933) has a somewhat complicated history, as it has been used in several ways and with different meanings and further, the original diagnosis is not too clear, making of it a nice imbroglio. Bamford \& Philippe (2001) and Philippe \& Bamford (2008) reviewed the history of this genus and finally recommended not to use the generic name Cedroxylon Kraus, at least for the "Gondwanic area". It is out of our scope here to analyze this matter in detail, and thus it is felt that the generic name Cedroxylon can confidently be eliminated from the list of woods present in the Triassic of southern Brazil. On the other hand, Philippe \& Thevenard (1996) showed that the genus Xenoxylon Gothan, used by Kräusel (1949) for Rau's specimen, seems to be exclusive to the boreal hemisphere, and also established that the species " $X$. canoasense" doubtfully belongs to it. In that paper, the authors cite the finding of some slides (numbered 25/6r-359) in the MNB (Berlin, see above) which seem to be original ones from Rau (1933). Philippe (in litt. 23-01-2016) from his early notes quotes about them: "radial pitting uniseriate, poorly preserved, possibly araucarian; cross fields not preserved". Thus, it seems we are certain in our assignment to Agathoxylon. From the evidence available (photographs and sketches by Rau \& Philippe's data) most characters indicate this genus, except by the apparent "xenoxyloid" pitting in his photograph (Rau, 1933, fig.1), a character that does not appear in the mentioned slides.

Agathoxylon, viz. A. africanum (Bamford) Kurzawe \& Merlotti, has been described in detail from Permian levels of southern Brazil (Kurzawe \& Merlotti, 2010) and also to the Upper Triassic-Jurassic Caturrita Formation of Rio Grande do Sul, by Crisafulli et al. (2016). Many other specimens have been quoted as uncertain species of Araucarioxylon (GuerraSommer et al., 1999; Guerra-Sommer \& Cazullo-Klepzig, 2000; Guerra-Sommer \& Scherer, 2002), but are distinct from A. canoasense. A conservative position is maintained here in relation to the species, accepting that proposed by Rau (1933) until more and better material is available for comparisons.

$$
\begin{gathered}
\text { A "conifer seed" in Kaokoxylon zalesskyi (Sahni) } \\
\text { Maheswari } \\
\text { (Figures 8-9) }
\end{gathered}
$$

Comments. Replicas of ovules and seed, preserved in iron oxi-hydroxides, was detected on a sector of a Kaokoxylon zalesskyi (Sahni) Maheswari wood, also preserved by densely impregnated iron oxides. In the wood is maintained the pith, the cuneiform primary xylem and the picnoxylic secondary one (Figure 8A). The reproductive structures, with an oblong form, with $3.2 \mathrm{~mm}$ long $\mathrm{x} 0.8$ wide, is inverted and adaxially inserted in one or perhaps two per scale (Figures $8 \mathrm{~B}-\mathrm{C}$ ). The integument seems to be thick in texture, and the nucellus, micropylar part (narrow) and megagametophitic tissue are well developed (Figure 8E). In one portion of the stem, two nucellar cavities enclosed by a common integument was detected (Figure $8 \mathrm{C}$ ). The integument seems to contain a sarcotesta and endotesta, although not very distinct. The nucellus may be differentiated from the integument, except in the chalazal area, and the megagametophitic tissue occupies all the space of the nucellar cavities. Part of the peduncle of this fructification is also preserved (Figures 8D-E; 9).

The specimen (ULVG 8532) originates from the same lacustrine laminated mudstones of São Luis outcrop (Caturrita Formation) where the Kaokoxylon species were detected and is housed at the Paleobotanical Collection of LaViGaea MHGEO, UNISINOS (Figure 8A). Later, researchers from the Zoobotanical Foundation of Rio Grande do Sul identified in the same beds a still unstudied little "araucarioide" cone ( $2.5 \mathrm{~cm}$ in diameter), covered by a crust of iron-rich clay, which conserves its tridimensional morphology and the inserted seeds.

Other evidence of such kind of special and exceptional preservation of plant fossils in the Triassic and Jurassic beds of South Brazil were preliminarily informed (Dutra \& Barboni, 2014) and are under study (Kerkhoff, 2017). This is aligned with the many announcements about similarly preserved plant fossils in other world deposits, most with correlate ages and preservation. They called the attention by its coincidence with signals of microbial activity as inductors of the iron deposits and favouring this unique preservation (e.g. Dunn et al., 1997; Bomfleur et al., 2007; Locatelli, 2014; Peterffy et al., 2016).

As already pointed by Crisafulli \& Dutra (2011), the herein described seed characters allow a general comparison with those found in the Araucariaceae representatives, like that from the Jurassic Cerro Cuadrado Formation, Argentine Patagonia (Stockey, 1975, 1977, 1978; Stockey \& Taylor, 1978), Rajmahal Series, India (Araucarites mittrii from Bohra \& Sharma, 1980), and other genera of Coniferales sensu lato (e.g. Nipaniostrobus Rao, 1943), and Sciadopitys (Saiki, 1992), from the Cretaceous of Japan. With A. mittrii it shares the presence of two nucellar cavities found in some specimens. However, in the here studied ovule the shrunk or wavy zig-zag appearance of the nucellus in the micropylar 

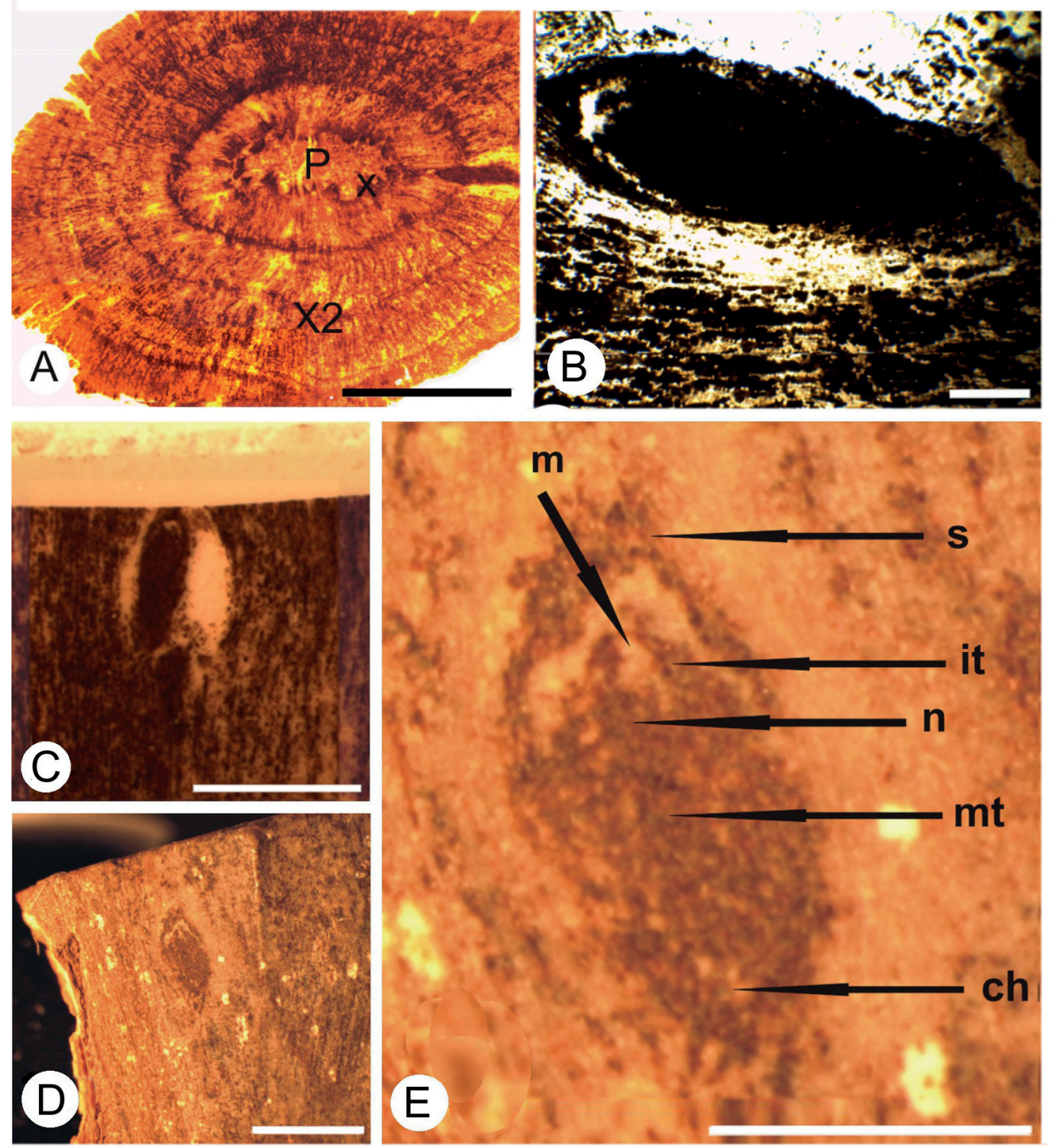

Figure 8. Kaokoxylon zalesskyi (Sahni) Maheswari (ULVG 8352) and associated seed. A, transversal section showing pith (P), wedge-shaped primary xylem (X) and picnoxylic secondary xylem (X2). Slide ULVG 8352a; B, longitudinal tangential section of secondary wood (ULVG 8352b), highlight the curving radial system which accompany the reproductive structure; C, longitudinal tangential section of secondary wood (ULVG 8352b), with the seed and an empty space left by another one; D, seed on the wood structure (ULVG 8352a); E, detail of D. Abbreviations: s, scale; m, micropyle; it, internal tegument; mt, megagametophytic tissue; ch, chalaza; $\mathbf{n}$, nucella. Scale bars: $A=25 \mathrm{~mm} ; \mathrm{B}=800 \mu \mathrm{m} ; \mathrm{C}=17 \mathrm{~mm} ; \mathrm{D}=5 \mathrm{~mm} ; \mathrm{E}=2.2 \mathrm{~mm}$.

zones, characteristic of A. mittrii and A. mirabilis Spegazzini (Stockey, 1975, 1978), was not observed.

The herein detected reproductive structure and some features of the associated wood also suggest an affinity with the Jurassic petrified cone, Pararaucaria patagonica Wieland emend. Escapa, Rothwell, Stockey \& Cúneo (Stockey, 1977; Stockey \& Taylor, 1978; Escapa et al., 2013), from Cerro Quadrado and Cañadon Calcáreo formations, to the cone axis of Araucariaceae from Stockey \& Taylor (1978) and, in longitudinal section, with the ovules of Mikasastrobus hokkaidoensis Saiki \& Kimura (1993) cones.

Taking all this data into account, it seems to be somewhat difficulties to establish whether these ovules were part of a definite "cone", or if they are attached to the wood as suggested by the surrounding tissues, where the tracheids seem to curve around the seed (Figures 8B-E). In any manner, and despite the poor state of preservation, the peculiar state of its preservation stimulates the detection of other similar occurrences.

\section{FINAL REMARKS}

The two new woods herein described from samples housed at the Walter Ilha Museum of São Pedro do Sul, help to enlarge the list of known gymnosperm wood taxa from the Triassic and Jurassic of Southern Brazil (Table 1). Therefore, an emphasis has to be put in describing more in situ material in order to make more clear the characteristics of the "fossil 


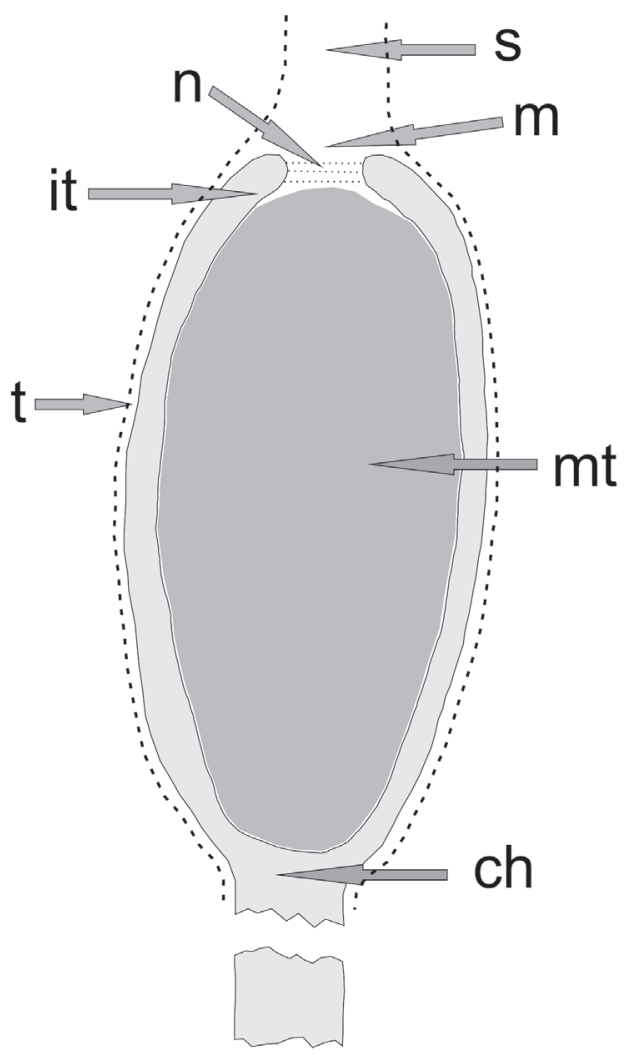

Figure 9. Sketch of the female reproductive structure. Abbreviations as in Figure 8.

forests" of Santa Maria and Caturrita formations.

To the CF, the present study attests for the first time, a more formal presentation of fertile organs linked to the Araucariaceae. Associated to the previous known female cone of Williamsonia potyporanae, also tridimensionally preserved and in the same mudstones facies of the São Luis outcrop (Barboni \& Dutra, 2013), is possible to inferred a flora of bennettites and small woody araucarioid conifers (by the caliber of its autochtonous roots and stems), which growed over crevasse splay deposits or river channel margins and were covered by the less ephemeral waters of a confined lake (oxbow?) or alluvial plain, in epochs of increasing humidity. A similar context was proposed by Colombi \& Parrish (2008) for the Valle de La Luna Member of the Ischigualasto Formation in northeastern Argentina. In the Ladinian-Carnian Santa Maria Formation, reproductive structures were known for a more long time, exhibiting relations with Dicroidium or its allied genus (Pteruchus and Umkomasia related forms) and with the Ginkgoaceae. Finally, the analysis made with the original material of Cedroxylon from Rau (1933), allow us to reject the presence of this genus in the list of taxa from Brazil, and still its relation with the Triassic assemblages.

All of them together, these findings expand our knowledge about the Mesozoic paleoxylotaphoflora of Brazil, and attest the radiation of the gymnosperms in the south-western interior areas of the Gondwana, under the influence of changing climates and environments. The data here discussed support a Middle-Late Triassic interval characterized by continuous landmasses and seasonal climates like proposed by Parrish (1993) and Preto et al. (2010) that allowed a uniform and dominant Dicroidium and Ginkgo flora to be distributed along the Gondwana. Between the end of Triassic and the Lower Jurassic (McElwain et al., 1999), despite the great extinction event worldwide detected, or because of it, this flora gave place to a more local and shrub size vegetation of conifers, which soon evolved to higher strata of wood forests adapted to the margins of low sinuosity rivers and to the crevasse splay deposits of the small rift basins resulting from extensional tectonic efforts (Zerfass et al., 2004). In all those processes the here detected wood floras and its associated facies are an important tool for the paleoenvironmental reconstructions.

\section{ACKNOWLEDGMENTS}

To J. Dallacosta, in charge of the Walter Ilha Museum in São Pedro do Sul, for the loan of the specimens here described. We deep thanks to S. Gnaedinger by its comments and profitable discussions about the identified seed. To M. Philippe (Lyon-France), which kindly supplied important data about Rau's specimen located in Berlin, we thanks the suggestions made, that lead to a profound review of the original manuscript. This work was done as part of A. Crisafulli's Projects PI 2010 - F015 (SGCyT-UNNE) and PI 2014 - F014 (SGCyT-UNNE), University of the Northeast, Corrientes, Argentina. Projects CNPq 401780/2010-4 and FAPERGS 1010122, coordinated by T.L. Dutra, and CNPq 401854/2010-4, coordinated by I.I. Leipnitz, for support to field works and other analysis. We are also thanks to the other anonymous reviewer by the extremely useful suggestions.

\section{REFERENCES}

Alves, L.S.R.; Guerra-Sommer, M. \& Dutra, T.L. 2005. Paleobotany and Paleoclimatology. In: E.M. Koutsoukos (ed.) Applied Stratigraphy, Netherlands, Springer, p. 179-202 (Topics in Geobiology 23). doi:10.1007/1-4020-2763-X_9

Ave-Lallemant, R. 1880. Viagem pela Província do Rio Grande do Sul (1858). São Paulo, Ed. Itatiaia-EDUSP, 417 p.

Bamford, M. \& Philippe, M. 2001. Jurassic-Early Cretaceous Gondwanan homoxylous woods: a nomenclatural revision of the genera with taxonomic notes. Review of Palaeobotany and Palynology, 113:287-297. doi:10.1016/S0034-6667(00)00065-8

Barboni, R. \& Dutra, T.L. 2013. New "flower" and leaves of Bennettitales from Southern Brazil and their implication in the age of the Lower Mesozoic deposits. Ameghiniana, 50:14-32. doi:10.5710/AMGH.28.11.2012.444

Barboni, R. \& Dutra, T.L. 2015. First record of Ginkgo-related fertile organs (Hamshawvia, Stachyopitys) and leaves (Baiera, Sphenobaiera) in the Triassic of Brazil, Santa Maria formation. Journal of South American Earth Sciences, 63:417-435. doi:10.1016/j.jsames.2015.08.001

Barboni, R.; Dutra, T.L. \& Faccini, U.F. 2016. Xylopteris (Frenguelli) Stipanicic \& Bonetti in the Middle-Upper Triassic (Santa Maria Formation) of Brazil. Ameghiniana, 53:599-622. doi:10.5710/ AMGH.11.07.2016.2897

Bardola, T.P.; Schmidt, I.D.; Guerra-Sommer, M. \& Da Rosa, A.A.S. 2010. Resultados preliminares sobre os lenhos fósseis 
gimnospérmicos do afloramento Água Boa, Município de São Pedro do Sul, RS, Triássico Superior. Porto Alegre, Sociedade Brasileira de Paleontologia, p. 26-27 (Paleontologia em Destaque 63).

Bardola, T.P.; Schmidt, I.D.; Guerra-Sommer, M. \& Schultz, C.L. 2009. Lenhos de Ginkgophyta em florestas petrificadas no Triássico Superior do Rio Grande do Sul, Brasil. Revista Brasileira de Paleontologia, 12:139-148. doi:10.4072/ rbp.2009.2.04

Beltrão, R. 1965. Paleontologia de Santa Maria e São Pedro do Sul, Rio Grande do Sul, Brasil. Boletim do Instituto de Ciências Naturais da Universidade Federal de Santa Maria, 2:3-114.

Berthelin, M.; Vozenin-Serra, C. \& Broutin, J. 2004. Phytogeographic and climatic implications of Permian woods discovered in Oman (Arabian Peninsula). Palaeontographica Abteilung B, 268:93-112.

Bohra, D. \& Sharma, B. 1980. Araucarites mittrii sp. nov. a petrified megastrobilus from the Rajmahal Hills, India. Ameghiniana, 17:3-9.

Bolzon, R.T. 1993. A lignitafoflora mesozóica do Rio Grande do Sul (Brasil): métodos de estudo e considerações sobre tafonomia, paleoecologia e paleoclimatologia. Dissertação de Mestrado, Programa de Pós-Graduação em Geociências, Universidade Federal do Rio Grande do Sul, 142 p. [unpublished].

Bolzon, R.T. \& Guerra-Sommer, M. 1994. Considerações sobre a tafonomia da lignitafoflora mesozóica do Rio Grande do Sul. Acta Geologica Leopoldensia, 39:109-115.

Bomfleur, B.; Schneider, J.; Schöner, R.; Viereck-Götte, L. \& Kerp, H. 2007. Exceptionally well-preserved Triassic and Early Jurassic floras from North Victoria Land, Antarctica. In: INTERNATIONAL SYMPOSIUM ON ANTARCTIC EARTH SCIENCES, 10, 2007. Extended Abstracts, Santa Barbara, IUGS, 034.

Cohen, K.M.; Finney, S.C.; Gibbard, P.L. \& Fan, J.-X. 2013. The ICS International Chronostratigraphic Chart. Episodes, 36:199-204.

Colombi, C.E. \& Parrish, J.T. 2008. Late Triassic environmental evolution in southwestern Pangea: plant taphonomy of the Ischigualasto Formation. Palaios, 23:778-795. doi:10.2110/ palo.2007.p07-101r

Crisafulli, A. \& Dutra, T.L. 2009. Kaokoxylon zalesskyi (Sahni) Maheswari en los niveles superiores de la Secuencia Santa Maria 2 (Formación Caturrita), Cuenca de Paraná, Brasil. GAEAJournal of Geosciences, 5:61-69. doi:10.4013/gaea.2009.52.02

Crisafulli, A. \& Dutra, T.L. 2011. Leño y estructuras reproductivas de Coniferales en la Formación Caturrita, Triásico SuperiorJurásico?, sul de Brasil. In: CONGRESSO BRASILEIRO DE PALEONTOLOGIA, 22, 2008. Atas, Natal, SBP, p. 317-322.

Crisafulli, A.; Dutra, T.L. \& Herbst, R. 2016. In-situ Late Triassic fossil woods from the fluvial channel deposits of the Caturrita Formation, Faxinal do Soturno, Rio Grande do Sul, Brazil. GAEA-Journal of Geoscience, 9:37-46. doi:10.4013/ gaea.2016.91.03

Crisafulli, A. \& Herbst, R. 2008. Maderas gimnospérmicas de la Formación Solca (Pérmico Inferior), provincia de La Rioja, Argentina. Ameghiniana, 45:737-751.

Crisafulli, A.; Herbst, R. \& Manza Storti, L. 2009. Maderas gimnospérmicas de la Formación Tres Islas (Pérmico Inferior) de Uruguay. GAEA-Journal of Geoscience, 5:1-14. doi:10.4013/ gaea.2009.51.01

Degani-Schmidt, I. \& Guerra-Sommer, M. 2016. Charcoalified Agathoxylon-type wood with preserved secondary phloem from the lower Permian of the Brazilian Parana Basin. Review of Palaeobotany and Palynology, 226:20-29. doi:10.1016/j. revpalbo.2015.12.003

Dunn, K.A.; McLean, R.J.C. \& Upchurch Jr., G.R. 1997. Enhancement of leaf fossilization potential by bacterial biofilms. Geology, 25:1119-1122. doi:10.1130/0091-7613(1997)025<1119:EOL $F P B>2.3 . C O ; 2$

Dutra, T.L. \& Barboni, R. 2014. Rediscovering the Brazilian Dicroidium flora: a fossil-lagerstätte in red beds? In: INTERNATIONAL PALAEONTOLOGICAL CONGRESS, 4, 2014. Abstracts, Mendoza, IPA, p. 701.

Erasmus, T. 1976. On the anatomy of Dadoxylon arberi Seward, with some remarks on the phylogenetical tendencies of its tracheid pits. Palaeontologia Africana, 19:127-133.

Escapa, I.H.; Cúneo, N.R.; Rothwell, G. \& Stockey, R.A. 2013. Pararaucaria delfueyoi sp. nov. from the Late Jurassic Cañadón Calcáreo Formation, Chubut, Argentina: insights into the evolution of the cheirolepidiaceae. International Journal of Plant Science, 174:458-470. doi:10.1086/668612

Faccini, U.F.; Giardini, A. \& Machado, J.L.F. 2003. Heterogeneidades litofaciológicas e hidroestratigrafia do sistema Aqüífero Guarani na região central do estado do Rio Grande do Sul, Brasil. In: P.S.G. Paim; U.G. Faccini \& R.G. Netto (eds.) Geometria, arquitetura e heterogeneidades de corpos sedimentares - estudos de casos, Unisinos, p. 147-173.

Faccini, U.F. \& Paim, P.S.G. 2001. Estratigrafia de sequências em depósitos continentais. In: H.J.P.S. Ribeiro (ed.) Estratigrafia de sequências - fundamentos e aplicações, Unisinos, p. 341-389.

García Esteban, L.; De Palacios, P.; Guindeo, C.A.; Lázaro, D.I.; González, F.L.; Rodríguez, S.Y.; Fernández, G.S.; Bobadilla, M.I. \& Camacho, A.A. 2002. Anatomía e identificación de maderas de coniferas a nivel de especies. Madrid, Coedición Fundación Conde del Valle de Salazar, Ediciones Mundi-Prensa, $421 \mathrm{p}$.

Guerra-Sommer, M. \& Cazzullo-Klepzig, M. 2000. The Triassic taphoflora from Paraná Basin, Southern Brazil: an overview. Revista Brasileira Geociencias, 30:481-485.

Guerra-Sommer, M.; Cazzulo-Klepzig, M. \& Iannuzzi, R. 1999. The Triassic taphoflora of the Paraná Basin, southern Brazil: a biostratigraphical approach. Journal of African Earth Sciences, 29:243-255.

Guerra-Sommer, M. \& Scherer, C.M.S. 2002. Sítios paleobotânicos do Arenito Mata nos Municípios de Mata e São Pedro do Sul, RS - Uma das mais importantes "florestas petrificadas" do planeta. In: C. Schobbenhaus; D.A. Campos; E.T. Queiroz; M. Winge \& M.L.C. Berbert-Born (eds.) Sitios Geológicos e Paleontológicos do Brasil, Brasília, DNPM/CPRM, p. 3-10.

Hartig, T. 1848. Beiträge zur Geschichte der Pflanzen und zur Kenntnis der norddeutschen Braunkohlen-Flora. Botanische Zeitung, 6:1-190.

Herbst, R. \& Lutz, A.I. 1988. Rhexoxylon brasiliensis n. sp. (Corystospermaceae, Pteridospermales) from the Upper Triassic Caturrita Formation - Brazil, with comments on biology and environment. Mededelingen Rijks Geologische Dienst, 42:21-31.

IAWA (The International Association of Wood Anatomists). 2004. IAWA list of microscopic features for softwood identification. IAWA Journal, 25:1-70. doi:10.1163/22941932-90000349

Isabelle, I. 1883. Viagem ao Rio Grande do Sul (1833-1834). $2^{\text {nd }}$ ed. Porto Alegre, Martins Livreiro, 165 p.

Jasper, A.; Uhl, D.; Guerra-Sommer, M.; Bernardes-de-Oliveira, M.E.C. \& Machado, N.T.G. 2011. Upper Paleozoic charcoal remains from South America: multiple evidences of fire events in the coal bearing strata of the Paraná Basin, Brazil. 
Palaeogeography, Palaeoclimatology, Palaeoecology, 306:205218. doi:10.1016/j.palaeo.2011.04.022

Jenisch, A.G.; Lehn, I.; Gallego, O.F.; Monferran, M.D.; Horodyski, R.S. \& Faccini, U.F. 2017. Stratigraphic distribution, taphonomy and paleoenvironments of Spinicaudata in the Triassic and Jurassic of the Paraná Basin. Journal of South American Earth Sciences, 80:1-20. doi:10.1016/j.jsames.2017.09.022

Kerkhoff, M.LK.H. 2017. Fósseis excepcionalmente preservados no Rio Grande do Sul: processos tafonômicos induzidos por microrganismos? São Leopoldo, Programa de Pós-Graduação em Geologia, Universidade do Vale do Rio dos Sinos, 59 p. (Seminário 1).

Kräusel, R. 1949. Die Fossilen Koniferen-Holzer (unter Ausschluss von Araucarioxylon Kraus): III. Teil. - Zur Diagnostik Lebender und Fossile Koniferen-Holzer. Palaeontographica Abteilung $B$, 83:111-203.

Kräusel, R. 1956. Der "Versteinerte Wald" in Kaokoveld, Südwest Afrika. Senckenbergiana Lethaea, 37:447-453.

Kurzawe, F. \& Merlotti, S. 2010. O complexo DadoxylonAraucarioxylon, Carbonífero e Permiano do Gondwana: estudo taxonômico do gênero Araucarioxylon. Pesquisas em Geociências, 37:41-50.

Leiva Veron, V.; Crisafulli, A.; Herbst, R.; Filippi, V. \& Molina, S. 2012. Guavirá, una nueva localidad con maderas fósiles de la Formación Tacuary (Pérmico Superior) de Paraguay. GAEAJournal of Geoscience, 8:67-81. doi:10.4013/gaea.2012.82.04

Locatelli, E. 2014. The exceptional preservation of plant fossils: a review of taphonomic processes and biases in the fossil record. In: M. Laflamme; J.D. Schiffbauer; A. Simon \& F. Darroch (eds.) Reading and writing of the fossil record: preservational pathways to exceptional fossilization, Bethesda, The Paleontological Society, p. 10-12 (Papers 20).

Lutz, A.; Crisafulli, A. \& Herbst, R. 2001. Contribución al estudio xiloflorístico de la Formación La Ternera, Triásico Superior (Chile). Ameghiniana, 38:119-127.

Maheshwari, H. 1966. Studies in the Glossopteris flora of India. On two new species of fossil wood from the Raniganj stage of Raniganj Coaldfield, Bengal. The Palaeobotanist, 13:148-154.

Maheshwari, H. 1967. Studies in the Glossopteris flora of India-28. On the fossil woods from the Raniganj Coalfield, Bengal. The Paleobotanist, 15:243-257.

Maheshwari, H. 1972. Permian wood from Antarctica and revision of some Lower Gondwana wood taxa. Palaeontographica Abteilung B, 203:1-82.

Martínez, N.L. \& Santonja, J.T. 1994. Paleontología. Conceptos y Métodos. Madrid, Ed. Síntesis, 334 p. (Colección Ciencias de la Vida 19).

McElwain, J.C.; Beerling, D.J. \& Woodward, F. 1999. Fossil plants and global warming at the Triassic-Jurassic boundary. Science, 285:1386-1390. doi:10.1126/science.285.5432.1386

Merlotti, S. \& Kurzawe, F. 2011. Lenhos permianos da Bacia do Paraná, Brasil: síntese e revisão taxonômica. GAEA-Journal of Geoscience, 7:19-33. doi:10.4013/gaea.2011.71.02

Milani, E.J.; Faccini, U.F.; Scherer, C.M.S.; Araújo, L.M. \& Cupertino, L.M. 1998. Sequences and stratigraphic hierarchy of the Paraná Basin (Ordovician to Cretaceous), Southern Brazil. Boletim do Instituto de Geociências da Universidade de São Paulo, 29:125-173.

Milani, E.J.; Melo, J.H.G.; Souza, P.A.; Fernandes, L.A. \& França, A.B. 2007. Bacia do Paraná. Boletim de Geociências da Petrobrás, 15:265-287.

Minello, L.F. 1993. As florestas petrificadas da região de São Pedro do Sul e Mata, RS: introdução ao estudo dos processos de fossilização e análise morfológica, legislação pertinente e análise do desenvolvimento da consciência preservacionista. Dissertação de Mestrado, Programa de Pós-Graduação em Geociências, Universidade Federal do Rio Grande do Sul, 484 p. [unpublished].

Minello, L.F. 1994a. As "florestas petrificadas" da região de São Pedro do Sul e Mata, RS. II. Processo de fossilização e composição mineral. Acta Geologica Leopoldensia, 39:57-73.

Minello, L.F. 1994b. As "florestas petrificadas" da região de São Pedro do Sul e Mata, RS. III. Analise morfológica megascópica, afinidades e considerações paleoambientais. Acta Geologica Leopoldensia, 39:75-91.

Pant, D. \& Singh, V. 1987. Xylotomy of some woods from Raniganj Formation (Permian), Raniganj Coalfield, India. Palaeontographica Abteilung B, 203:1-82.

Parrish, J.T. 1993. Climate of the supercontinent Pangea. Journal of Geology, 101:215-233. doi:10.1086/648217

Peterffy, O.; Calner, M. \& Vajda, V. 2016. Early Jurassic microbial mats - A potential response to reduced biotic activity in the aftermath of the end-Triassic mass extinction event. Palaeogeography, Palaeoclimatology, Palaeoecology, 464:7685. doi:10.1016/j.palaeo.2015.12.024

Philippe, M. \& Bamford, M. 2008.A key to morphogenera used for Mesozoic conifer-like woods. Review of Palaeobotany and Palynology, 148:184-207. doi:10.1016/j.revpalbo.2007.09.004

Philippe, M. \& Thevenard, F. 1996. Distribution and paleoecology of the Mesozoic wood genus Xenoxylon: palaeoclimatological implications for the Jurassic of Western Europe. Review of Palaeobotany and Palynology, 91:353-370. doi:10.1016/00346667(95)00067-4

Pires, E.F. \& Guerra-Sommer, M. 2004. Sommerxylon spiralosus from Upper Triassic in southernmost Paraná Basin (Brazil): a new taxon with taxacean affinity. Anais da Academia Brasileira de Ciências, 76:595-609. doi:10.1590/S0001-37652004000300013

Pires, E.F.; Guerra-Sommer, M. \& Scherer, C.M.S. 2005. Late Triassic climate in southernmost Parana Basin (Brazil): evidence from dendrochronological data. Journal of South American Earth Sciences, 18:213-221. doi:10.1016/j.jsames.2004.10.004

Prasad, M. 1986. Xylotaphoflora of the Kamthi Formation, Indian Lower Gonwana with remarks on the biostratigraphic importance of its taphoflora. Palaeontographica Abteilung B, 201:111-134.

Preto, N.; Kustatscher, E. \& Wignall, P.B. 2010. Triassic climates - State of the art and perspectives. Palaeogeography, Palaeoclimatology, Palaeoecology, 291:1-10. doi:10.1016/j. palaeo.2010.03.015

Rao, A. 1943. Nipaniostrobus, a new genus of Dacrydium like seed bearing cones, and other silicified plants from the Rajmahal series. Proceedings of the National Academy of Sciences, 13:113-133.

Rau, W. 1933. Cedroxylon canoasense, una madera fósil nueva del Rio Grande del Sur. Revista Sudamericana Botánica, 1:63-68.

Rohn, R.; Dutra, T.L. \& Cabral, M.V.B. 2014. Conchostráceos como evidência de níveis jurássicos na Formação Caturrita, Faxinal do Soturno, Rio Grande do Sul, Brasil. Geologia USP, Série Cientifica, 14:3-20. doi:10.5327/Z1519-874X201400010001

Rößler, R. et. al. 2014. Which name(s) should be used for Araucarialike fossil wood? - Results of a poll. Taxon, 63:177-184. doi:10.12705/631.7

Saiki, K. 1992. A new Sciadopityaceous seed cone from the Upper Cretaceous of Hokkaido, Japan. American Journal of Botany, 79:989-995. doi:10.1002/j.1537-2197.1992.tb13688.x

Saiki, K. \& Kimura, T. 1993. Permineralized taxodiaceous seed 
cones from the upper cretaceous of Hokkaido, Japan. Review of Palaeobotany and Palynology, 76:83-96. doi:10.1016/00346667(93)90081-5

Santos, E.L. \& Moreira, J.L.P. 1987. Projeto sítios paleontológicos do estado do Rio Grande do Sul - Fase 1. Porto Alegre, Ministério das Minas e Energia, Departamento Nacional de Produção Mineral (DNPM), Seção de Geologia e Mineralogia, $15 \mathrm{p}$.

Soares, P.C.; Soares, A.P. \& Bettú, D.F. 2014. Formação da sequência triássico-jurássica na Bacia do Paraná. Boletim de Geociências da Petrobras, 22:135-160.

Stockey, R. 1975. Seeds and embryos of Araucaria mirabilis. American Journal of Botany, 62:856-868. doi:10.1002/j.1537-2197.1975. tb14126.x

Stockey, R. 1977. Reproductive biology of Cerro Cuadrado (Jurassic) fossil conifers: Pararaucaria patagonica. American Journal of Botany, 64:733-744. doi:10.1002/j.1537-2197.1977.tb11915.x

Stockey, R. 1978. Reproductive biology of Cerro Cuadrado fossil conifers: ontogeny and reproductive strategies in Araucaria mirabilis (Spegazzini) Windhausen. Palaeontographica Abteilung B, 166:1-15.
Stockey, R. \& Taylor, T. 1978. On the structure and evolutionary relationship of the Cerro Cuadrado fossil conifer seedlings. Botanical Journal of the Linnean Society, 76:161-176. doi:10.1111/j.1095-8339.1978.tb01504.x

Zeiller, M. 1895. Note sur la flore fossile des gisements houlliers do Rio Grande do Sul (Brasil meridional). Bulletin Societé Geologique de France, 23:601-629.

Zerfass, H.; Chemale Jr., F.; Schultz, C.L. \& Lavina, E. 2004. Tectonics and sedimentation in southern South America during Triassic. Sedimentary Geology, 166:265-292. doi:10.1016/j. sedgeo.2003.12.008

Zerfass, H.; Lavina, E.; Schultz, C.L.; Garcia, A.J.V.; Faccini, U.F. \& Chemale Jr., F. 2003. Sequence stratigraphy of continental Triassic strata of Southermost Brazil: a contribution to Southwestern Gondwana palaeogeography and palaeoclimate. Sedimentary Geology, 161:85-105. doi:10.1016/S00370738(02)00397-4

Received in 02 July, 2016; Accepted in 12 December, 2017. 


\section{TRIBUTE TO PE. DANIEL CARGNIN AND DR. RAFAEL HERBST}

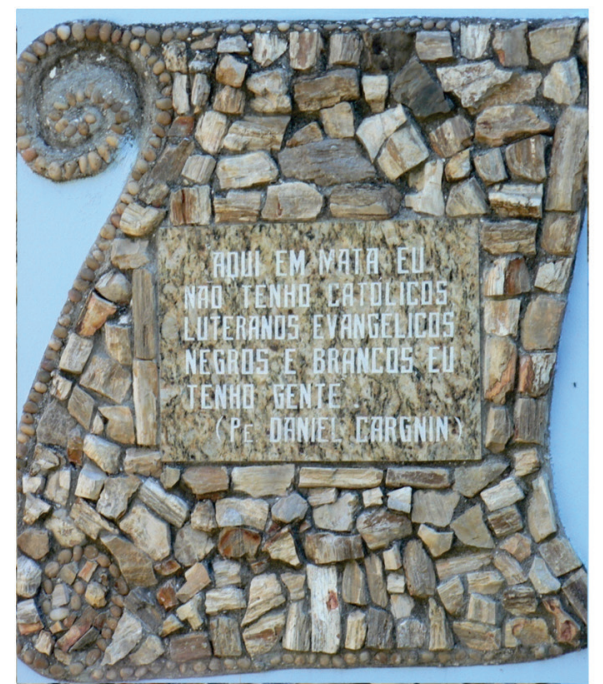

"Here in Mata I don't have catholics, lutherans, evangelics, black or whites, I have people" (Pe. Daniel Cargnin)

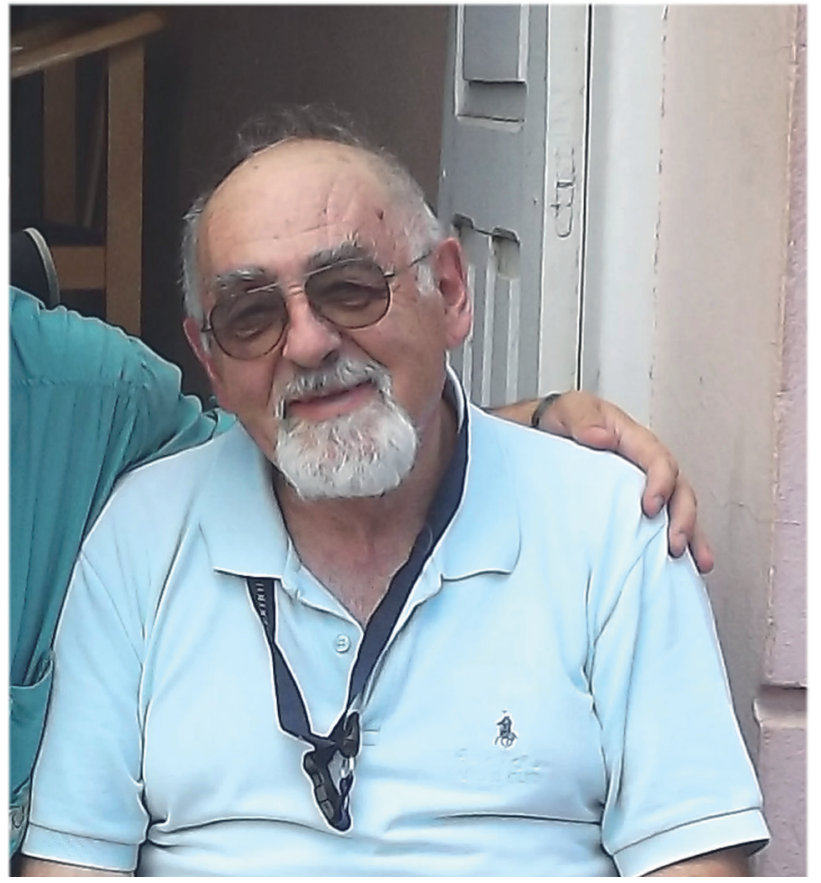

Dr. Rafael Herbst

We want to leave our homage to two lost persons in the last years that had a great significance in our lives and in the research with Paleobotany in Brazil, by their dedication and the splendid work made.

Father Daniel Cargnin (1930-2002), priest of Mata during 20 years and an amateur paleontologist, while carrying out his main mission of protecting the men soul, also was fascinated by the numerous occurrences of fossil woods in the city terrains. Then, he convinced the inhabitants of Mata and of the surroundings to use the fossil woods as an ornament in the streets, squares and buildings, in a way of preserving and protecting that wealth. His clairvoyance is attested by the words in the figure here shown, written by him at the end of the 1970`s, and more than this, by its big concern for humanity.

Dr. Rafael Herbst (1936-2017), despite being one of the greatest geologists and paleobotanist from Argentina, and having trained a great amount of young researchers in the study of fossil woods, was also a "globetrotter", fond by the South American landscapes. During a long time he comes to Brazil, searching for comparative forms between the Triassic deposits of his and of our country. In one of these trips, a sample showed by Dr. Walter Ilha, director of the Museum, at São Pedro do Sul, allowed him to describe, with Alicia Lutz, the exclusive pteridosperm wood Rhexoxylon brasiliensis from the Paraná Basin deposits of Rio Grande do Sul, expanding our knowledge about of the "Dicroidium Flora". This tribute to Pe. Cargnin was a desire of Dr. Herbst during the time off we were involved in the present work, and the herein made homage (with the plaque in the entrance of the Church of Mata) had been prepared by him. 